При новощъ пзс.ььованіш въ присутствіп 5 врачей зондъ чрезъ дно матки проникъ въ брюпную полость по самую рукоятку и головка его прощүпывалась чрезъ брюшные покровы около пупка.

Рьшено было давать больной чрезъ 3 часа по $1 / 2$ грана кодеина въ надежд', что онъ ножеть (? Рефб.) остановить истеченіе, что вскор's и случилось. Больная могла отказаться уже оть мочепріемника, потому что жидкость выдьлялась лишь по каплямъ. Когда же пришлось отказаться оть кодегна, который производиль наклонность ко сну и запоры, то истеченіе возобновилось въ количеств'ь 4-16 унцъ ежедневно. Теперь, т. е. 6 мьсядевъ спустя посль родовъ, больная при спокойнощъ положеніи выдьляеть очень мало жидкостп или даже ничего; при ходьбь же отъ 2 унцъ до пинты $($ пинта $=1 / 2$ кварта $=12$ унцамъ $)$.

0чевидно, говорить авторъ, здысь сүществовало въ днь матки открытое отверстіе (всльдствіе неосторожнаго зондированія? (Рефб.), сообщавпееся с'ь брғюшною полостью и пропускавшее черезъ себя отдыленіе брюшины.

Можеть ли, спрапиваеть авторъ, операція или какой другой способъ псцьлить такую больную, которая несмотря на хорошее обцее здоровье, продолжаеть оставаться инвалидомъ.

\title{
Ф. Кюнъ.
}

76. Humiston. On the uses of cocaine in gynecological surgery. (Journ. of the Amer. Med. Assoc. July 11, 1891). Употребленіе кокаина въ гинекологичской хирургіи.

Авторъ горячо хвалить мъстную анэстезію кокаиномь при нькоторыхъ гинекологическіхх операціяхъ. Онъ испыталь его въ сльвдующихь случаяхъ:

1) При расширеніп шейки и выскаблпваніп полости маткп. Сначала авторь впрыскиваеть въ заднюю губу шейки матки $1 / 2$ шприца Праваца съ $4^{\%} \%$ растворошь кокаина; затьнь по мьр'ь расширенія канала еще два штрица того же раствора въ различныя части шейкн. Когда матка пропускаеть внутриматочный ппрнць, онь вщрыскиваеть въ полость ея полный пприщъ Праваца съ $10 \%$ растворомъ көкаина и затьмъ производить выскабливаніе, которое при гакихь условіяхъ совершенно не бользненно пли очень мало больззненно.

2) Trachelorrhaphia при прим'вненіи полудрахмы $5 \%$ раствора кокаина дыљается совершенно безбользненною операціею.

3) При возстановленіи промежности по лоскутному способу достаточно 13-14 дыленій 4\% раствора кокашна для анэстезіи всего операціоннаго поля.

4) Дважды авторь расширяль уретру при fissura urethrae, при чемъ кокаинъ дьлаль операцію весьма мало бользненною.

5) 0днажды авторь участвоваль при операціп Alexander'a, гды было съ успьхомъ прпмынено пва грана кокаина, впрыснутаго по одному грану въ каждую сторону.

В0 всь̌хъ случаяхъ преимущество коканна предъ другими анэстезирующими средствами заключается въ простоть примьненія, быстроть и равномьрности дыйствія его (на нервныхъ и возбужденныхъ особъ онъ дыйствуетъ одинаково, какъ п на спокойныхъ паціентокъ). Наконець, что очень важно, 
кокаинъ даетъ возможность избьгать сльдующей носль хлороформа или эөира рвоты, которая сама уже способна уничтожпть шлоды операдін, напр. посль зашиванія промежности.

Ф. КюНъ.

77. Sellmann. The use of vaginal tampons. (Journ. of the Amer. Med. Assoc. July 11, 1891). Употребленіе влагалищныхъ тампоновъ.

Цњль этой статьи-обратить вниманіе гинекологовь на опасности, сопџяженныя съ употребленіемъ влагалищныхъ тащпоновъ,--опасностп, которыхъ гинекологи въ своенъ үвлеченіи по сейчась не занычаютъ.

Для гэмостатической цыли рњдко есть необходимость въ тампонахъ, liторые въ этихъ случалхъ могуть принести больным болье вреда, чьын пользы. Авторь оправдываеть примнненіс пхь съ цьлью вызвать союращепін матки или разрыхленіе шейки прп пропвводстье искусственныхъ прежревре-

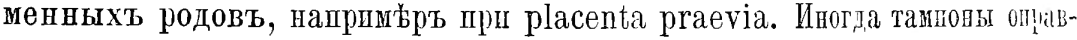
дываются и при кровотеченіяхъ, зависяпихъ отъ фибропдовь матінг.

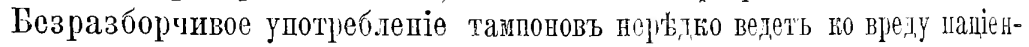

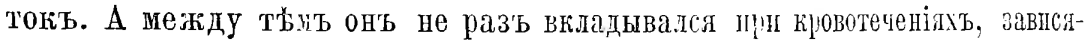

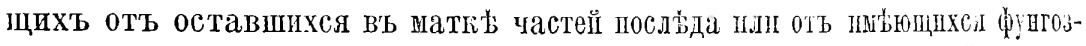
ныхъ разращеній. 0тыщите, говоригъ авторь, причпу кровотеченій, удалиге ее, и кровотеченіе остановитсяг. Придерживаясь этого правпла, ножно, подойн

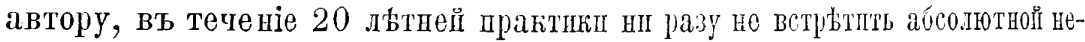
обходимости въ тампонахъ радпг кровотетеній.

Такой тампонь, лежащій предъ самымь оs cervicis. конечно, задержнть въ маткь не только гровь, но и всякое другое отдьленіе. Скопленіе валержанныхъ жид,костеї можеть достшгнуть 'такої степенш, что, растянувъ матку

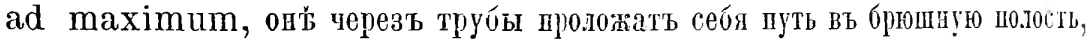
гды могуть повести къ самымъ серьезным заболываніямь восна.літельпаго характера. Кромь того тампонъ препятствуеть нормальнынь отправленіямь

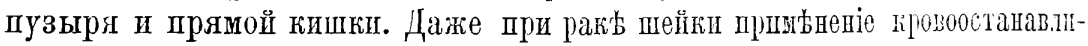
вающаго средства in lосо лучше тампона.

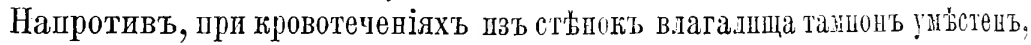
потому что давленіем'ь своимь на гіровоточащіе сосуды онъ виолнь доститаеть своего назначенія.

Нерьдко влагалищный тампонь употрео́ляется съ цблью предохраниц наружные половые органы оть ьдкаго ды̆̆ствія патологшескаго секрета дл нами же примьненнаго лькарственнаго средства. II въ этихъ случаяхъ въ

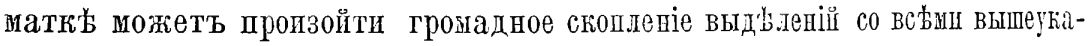
занными грустныни посльдствіями. Выроятно, не јазь уже такци способонъ мы сами заставляли гоноррею распространиться съ ніжнпхъ отрђзковь половыхъ путей вверхъ по половозу каналу.

Польза тампоновъ при ракь шейки, повторяю, очень соннительна.

Болье смысла имьеть такой тампов прг воспаленіяхь щрпдатковъ. Түть онъ, поддерживая и какъ бы фиссируя патку, предохравяеть восдаленные органы оть смьщеній п влеченій ихъ щаткою.

Льченіө тампонами воспаленій пейки и тьла маткп не оправпало т'ххъ 